\title{
Airway Remodeling in the Asthma Model: Is there Standardization in this Evaluation?
}

\author{
Lidiane Maria Boldrini Leite*1, Pedro Vicente Michelotto $\mathrm{Jr}^{2}$, Sérgio Adriane Bezerra de Moura ${ }^{3}$, Paulo \\ Roberto Slud Brofman ${ }^{1}$ and Alexandra Cristina Senegaglia*1 \\ ${ }^{1}$ Core for Cell Technology, Pontifícia Universidade Católica do Paraná (PUCPR), Curitiba, Brazil \\ ${ }^{2}$ Department of Animal Science, Pontifícia Universidade Católica do Paraná (PUCPR), Curitiba, Brazil \\ ${ }^{3}$ Department of Morphology, Universidade Federal do Rio Grande do Norte (UFRN), Natal, Brazil \\ *Corresponding author: Alexandra Cristina Senegaglia, Core for Cell Technology, Curitiba, Paraná, Brazil \\ Lidiane Maria Boldrini Leite, Core for Cell Technology, Curitiba, Paraná, Brazil
}

\section{ARTICLE INFO}

Received: 业 February 14, 2019

Published: 幽 February 25, 2019

Citation: Leite LMB, Michelotto Jr PV, Moura SAB, Brofman PRS, Senegaglia AC. Airway Remodeling in the Asthma Model: Is there Standardization in this Evaluation?. Biomed J Sci \& Tech Res 15(1)-2019. BJSTR. MS.ID.002655.

\begin{abstract}
Asthma is a chronic inflammatory disease characterized by obstruction of airflow causing respiratory difficulties at various intensities. Airways inflammation has an important role in the pathophysiology of asthma. The inflammatory process in the airways promotes significant changes in the respiratory structures called airway remodeling, which represents a late and permanent response to tissue injury. This review aimed emphasize the importance of histological evaluation of airway remodeling in the asthma experimental model. There are several methods of histopathological analysis available today, but the implementation of a standardized methodology would help in the damages caused by the allergens and future assessments of possible therapies used to treat the disease.
\end{abstract}

Keywords: Asthma; Airway; Airway Remodeling; Histological Evaluation

Abbreviations: TH2: T helper 2; IgE: Immunoglobulin E; OVA: Ovalbumin; H\&E: Hematoxylin \& Eosin; PAS: Periodic-Schiff Acid; MT: Masson's Trichrome

\section{Introduction}

Asthma is a chronic inflammatory disease characterized by obstruction of airflow causing respiratory difficulties at various intensities [1]. It represents a major cause of physical disability, affecting 300 million people worldwide [2]. Airways inflammation has an important role in the pathophysiology of asthma, which is characterized mainly by the TH2 type immune response. The inflammatory process in the airways of individuals with asthma promotes significant changes in the respiratory structures, induced by repeated lesions and repairs [3]. This review aimed emphasize the importance of histological evaluation of airway remodeling in the asthma experimental model.

\section{Airway Remodeling}

Airway remodeling represents a late and permanent response to tissue injury, mainly caused by primary irritants. It is characterized by tissue and cellular changes in the bronchioles, such as increased collagendeposition, hyperplasiaandsmoothmusclehypertrophy, increased vascularization, basement membrane thickening and epithelial layer and epithelial desquamation, goblet cell metaplasia, mucus production and hypersecretion [4]. Inflammatory cells participate of this process in different intensities (Figure 1) [5]. In the normal airway, the distribution of collagen and other components of the extracellular matrix is in equilibrium due to regulation of synthesis and degradation. In asthma, interruption of homeostasis results in increased deposition of extracellular matrix, especially in the reticular lamina, lamina propria and submucosa [6]. Smooth muscle thickening is primarily responsible for bronchoconstriction of the airways and persistent airflow obstruction. Muscle layer thickening may be caused by hyperplasia, hypertrophy or migration and differentiation of progenitors such as myofibroblasts [7]. Further to the center of the bronchiole is located the epithelium, which is considered a physical barrier that protects the body 
against environmental influences. Its function is dependent of cell integrity and protein interaction in junctional intercellular complexes, especially the Tight Junctions. Failure in this complex makes the epithelium permeable to allergens and other agents to airway tissue [8]. In the case of asthma, due to the metaplasia and hyperplasia of the goblet cells, the mucus hypersecretion has contributed intensively to the morbidity and mortality due to this disease, because before an inflammatory process, the increased mucus production causes the narrowing of the airways and asphyxia, which may result in death [9]. The currently available treatments minimize the symptoms in the patients, reducing the inflammation. However, there is still no therapy that prevents or reverses the changes resulting from airway remodeling.

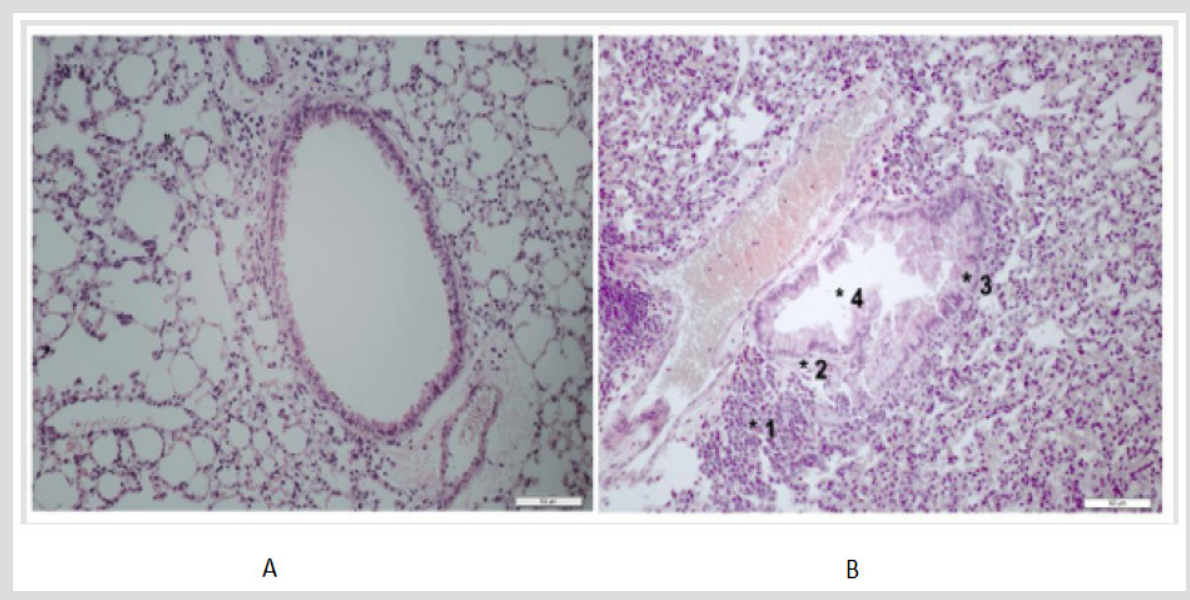

1) Presence of inflammatory infiltrate,

2) Muscle thickening,

3) Epithelial thickening,

4) Epithelial cells desquamation into the lumen of the bronchioles.

Figure 1: Lung histological sections of Balb/c mice. A. Airway showing aspect of normality. B. Airway with an intense lung remodeling. Magnification: 200x.

\section{Asthma Experimental Model}

Preclinical models have been widely used in the search for understanding the pathophysiological events responsible for the development of asthma. Several aspects of this complex disease have been investigated experimentally, and it is hoped that further progress in this area will facilitate the development of new effective therapeutic approaches [10]. However, most of the studies used the murine, in which the Balb/c $[11,12]$ and C57BL/6 [13,14] lineage is highlighted. Balb/c and C57BL/6 mice are isogenic animals that develop a strong TH2 immune response with increased IgE levels after exposure to ovalbumin (OVA), a gold standard allergen for assessing the allergic response [15,16]. The experimental asthma models in mice do not accurately reproduce the human disease, since the clinical signs are difficult to investigate. However, animal models have aided in understanding the pathophysiological mechanisms inherent to the disease and in identifying new targets for therapeutic interventions and potential treatments [17].

\section{Airway Remodeling Evaluation}

Usually, at the end of the experimental asthma study, the mice are submitted to euthanasia mainly by anesthetic overdose [18] or cervical dislocation [11]. The lungs are then removed and fixed in formalin or paraformaldehyde. After this time, the lungs are transferred to cassettes and processed by histological techniques. Then, the remodeling could be evaluated in lung histological sections through the staining: Hematoxylin \& Eosin (H\&E), PeriodicSchiff Acid (PAS) and Masson's Trichrome (MT) but, there are many variables in the procedures used (Table 1). The H\&E staining allows the lung morphology evaluation, the presence and inflammatory infiltrate intensity in the peribronchiolar, perivascular and adjacent area, the smooth muscle layer thickening and changes in the epithelium, with emphasis on cellular desquamation for the lumen of the bronchioles. PAS can identify the mucus produced by goblet cells and the distribution of these cells. The MT identifies collagen deposition in the peribronchiolar and perivascular region in the histological sections [19]. Lung histological involvement is a relevant aspect of asthma, there is no established standard of assessment. We believe that all the criteria are important, but the standardization of tissue damage analysis could help researchers to reproduce protocols available in the literature and ensure the effectiveness of the experimental model developed. As each investigator uses a different method of airway remodeling evaluation, it is difficult to compare results involving new therapies for asthma, since the baseline condition of the disease may not be the same for the different conditions evaluated. 
Table 1: Evaluation methods of airway remodeling in asthma induction model. Staining: Hematoxylin \& Eosin (H\&E), PeriodicSchiff Acid (PAS) and Masson's Trichrome (MT).

\begin{tabular}{|c|c|c|c|c|c|}
\hline Article & Histological procedure & Evaluation & H\&E & PAS & MT \\
\hline Dai et al. [18] & $10 \%$ formalin & $\begin{array}{l}5 \text { airway sec- } \\
\text { tions }\end{array}$ & $\begin{array}{l}\text { Scoring system: Scale } \\
\text { from } 0 \text { to } 5 \text { for inflam- } \\
\text { matory infiltration in } \\
\text { the peribronchiolar } \\
\text { area. }\end{array}$ & $\begin{array}{l}\text { Scoring system: } \\
\text { Scale from } 0 \text { to } 5 \\
\text { for PAS- positive } \\
\text { cells }\end{array}$ & $\begin{array}{l}\text { Subepithelial fibrosis was evaluated } \\
\text { by the Digimizer software. The area of } \\
\text { collagen deposition and the perimeter } \\
\text { of basement membrane of bronchioles } \\
\text { were measured, and it was evaluated by } \\
\text { scoring system: Scale from } 0 \text { to } 5 \text {. }\end{array}$ \\
\hline Leite et al. [19] & $10 \%$ buffered formalin & $\begin{array}{c}30 \text { bronchioles } \\
\text { (15 from each } \\
\text { lung) }\end{array}$ & $\begin{array}{l}\text { Scoring system: Scale } \\
\text { from } 0 \text { to } 3\end{array}$ & $\begin{array}{l}\text { PAS-positive cells } \\
\text { were evaluated } \\
\text { into } 8 \text { regions and } \\
\text { then by scoring } \\
\text { system: Scale } \\
\text { from } 0 \text { to } 3 .\end{array}$ & Scoring system: Scale from 0 to 3 . \\
\hline $\begin{array}{l}\text { Goodwin et al. } \\
\text { [20] }\end{array}$ & $4 \%$ paraformaldehyde & $\begin{array}{l}4 \text { airways per } \\
\text { animal }\end{array}$ & $\begin{array}{l}\text { Scoring system: Scale } \\
\text { from } 0 \text { to } 3 \text { for the } \\
\text { presence and inten- } \\
\text { sity of peribronchial } \\
\text { infiltrate }\end{array}$ & Not investigated & Not investigated \\
\hline Kang et al. [21] & $\begin{array}{l}4 \% \text { neutral buffered } \\
\text { formalin }\end{array}$ & 8 fields & $\begin{array}{l}\text { Scoring system: } \\
\text { Scale from } 0 \text { to } 3 \text { for } \\
\text { peribronchial and } \\
\text { perivascular inflam- } \\
\text { mation, thicknesses } \\
\text { of epithelium and } \\
\text { smooth muscle layer. }\end{array}$ & $\begin{array}{l}\text { Five-point } \\
\text { scoring system } \\
\text { was used for eval- } \\
\text { uating goblet cell } \\
\text { hyperplasia. Scale } \\
\text { from } 0 \text { to } 4\end{array}$ & Not investigated \\
\hline $\begin{array}{l}\text { Ou-Yang et al. } \\
{[22]}\end{array}$ & Formalin & Not specified & $\begin{array}{l}\text { Scoring system: } \\
\text { Scale from } 0 \text { to } 4 \text { for } \\
\text { peribronchial and } \\
\text { perivascular inflam- } \\
\text { mation }\end{array}$ & Not investigated & Not investigated \\
\hline Ge et al. [23] & $4 \%$ paraformaldehyde & Not specified & $\begin{array}{l}\text { Image Pro-Plus } \\
\text { software was used } \\
\text { to identify cellular } \\
\text { inflammation. Scoring } \\
\text { system: Scale from } \\
0 \text { to } 4\end{array}$ & $\begin{array}{l}\text { Scoring system: } \\
\text { Scale from } 0 \text { to } 4 \\
\text { for PAS- positive } \\
\text { goblet cells }\end{array}$ & $\begin{array}{c}\text { The ratio of the area of trichrome staining } \\
\text { to the basement membrane perimeter } \\
\text { was measured for quantify collagen } \\
\text { deposition }\end{array}$ \\
\hline $\begin{array}{c}\text { Mohammadian } \\
\text { et al. [24] }\end{array}$ & Formalin & $\begin{array}{l}5 \text { airway sec- } \\
\text { tions }\end{array}$ & $\begin{array}{l}\text { Scoring system: } \\
\text { Scale from } 0 \text { to } 5 \\
\text { for peribronchiolar } \\
\text { inflammation. }\end{array}$ & $\begin{array}{l}\text { Scoring system: } \\
\text { Scale from } 0 \text { to } 5 \text {. } \\
\text { PAS-positive cells }\end{array}$ & $\begin{array}{l}\text { Subepithelial fibrosis was asses using the } \\
\text { Digimizer software. The area of collagen } \\
\text { deposition and the perimeter of basement } \\
\text { membrane of bronchioles were measured, } \\
\text { and it was evaluated by scoring system: } \\
\text { Scale from } 0 \text { to } 5 \text {. }\end{array}$ \\
\hline $\begin{array}{l}\text { Ogulur et al. } \\
\qquad[25]\end{array}$ & $10 \%$ formalin & $\begin{array}{l}\text { Airways were } \\
\text { classified } \\
\text { according to } \\
\text { their diameter } \\
\text { (distal or prox- } \\
\quad \text { imal) }\end{array}$ & $\begin{array}{l}\text { A minimum of } 5 \\
\text { points of each airway } \\
\text { was measured for } \\
\text { evaluate epithelium } \\
\text { thicknesses, smooth } \\
\text { muscle layers and } \\
\text { basement membrane }\end{array}$ & $\begin{array}{c}\text { A total of } 500 \\
\text { goblet cells were } \\
\text { counted }\end{array}$ & Not investigated \\
\hline $\begin{array}{l}\text { Royce et al. } \\
\text { [26] }\end{array}$ & $\begin{array}{l}10 \% \text { neutral buffered } \\
\text { formaldehyde }\end{array}$ & $\begin{array}{l}\text { Five airways } \\
\text { per section }\end{array}$ & Not investigated & $\begin{array}{l}\text { Goblet cell were } \\
\text { analyzed using } \\
\text { Image Scope } \\
\text { software }\end{array}$ & $\begin{array}{l}\text { Scoring system: Scale from } 0 \text { to } 4 \text { for } \\
\text { peribronchiolar inflammation. Epithelial } \\
\text { thickness and subepithelial deposition } \\
\text { were measured. }\end{array}$ \\
\hline $\begin{array}{l}\text { Bonfield et al. } \\
\text { [27] }\end{array}$ & $10 \%$ formalin & Not specified & Not specified & Not investigated & Not specified \\
\hline
\end{tabular}

\section{Conclusion}

Airway remodeling is a result of significant tissue changes induced by repeated injury and repair processes in individuals with asthma. There are several methods of histopathological analysis available today, but the implementation of a standardized methodology would help in the damages caused by the allergens and future assessments of possible therapies used to treat the disease. 


\section{References}

1. Taylor DR, Bateman ED, Boulet LP, Boushey HA, Busse WW, et al. (2008) A new perspective on concepts of asthma severity and control. Eur Respir J 32(3): 545-554.

2. (2017) Global Initiative for Asthma.

3. Mullane K (2011) Asthma translational medicine: report card. Biochem Pharmacol 82(6): 567-585.

4. Hirota N, Martin JG (2013) Mechanisms of airway remodeling. Chest 144(3): 1026-1032.

5. Cho KS, Park MK, Kang SA, Park HY, Hong SL, et al. (2014) Adiposederived stem cells ameliorate allergic airway inflammation by inducing regulatory T cells in a mouse model of asthma. Mediators Inflamm 2014: $1-10$.

6. Royce SG, Cheng V, Samuel CS, Tang ML (2012) The regulation of fibrosis in airway remodeling in asthma. Mol Cell Endocrinol 351(2): 167-175.

7. Berair R, Saunders R, Brightling CE (2013) Origins of increased airway smooth muscle mass in asthma. BMC Med 11(1): 145

8. Xiao C, Puddicombe SM, Field S, Haywood J, Broughton Head V, et al. (2011) Defective epithelial barrier function in asthma. J Allergy Clin Immunol 128(3): 549-556.

9. Kondo M, Nakata J, Arai N, Izumo T, Tagaya E, et al. (2012) Niflumic acid inhibits goblet cell degranulation in a Guinea pig asthma model. Allergol Int 61(1): 133-142.

10. Gualdi LP, Pereira AC, Masiero L, Nuñez NK, Cao R, et al. (2010) Murine models for asthma research: An updated critical analysis. Scientia Medica 20(3): 236-242.

11. Zeng SL, Wang LH, Li P, Wang W, Yang J (2015) Mesenchymal stem cells abrogate experimental asthma by altering dendritic cell function. Mol Med Rep 12(2): 2511-2520.

12. Zhu X, Li Q, Hu G, Wang J, Hu Q, et al. (2018) BMS-345541 inhibits airway inflammation and epithelial-mesenchymal transition in airway remodeling of asthmatic mice. Int J Mol Med 42(4): 1998-2008.

13. Shi JP, Li XN, Zhang XY, Du B, Jiang WZ, et al. (2015) Gpr97 is dispensable for inflammation in ova-induced asthmatic mice. PLoS One 10(7): 1-13.

14. Liang L, Hur J, Kang JY, Rhee CK, Kim YK, et al. (2018) Effect of the antiIL-17 antibody on allergic inflammation in an obesity-related asthma model. Korean J Intern Med 33(6): 1210-1223.

15. Shin YS, Takeda K, Gelfand EW (2009) Understanding asthma using animal models. Allergy Asthma \& Immunol Res 1(1): 10-18.

\section{ISSN: 2574-1241}

DOI: 10.26717/BJSTR.2019.15.002655

Alexandra CS, Lidiane Maria BL. Biomed J Sci \& Tech Res

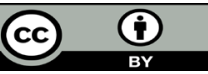

This work is licensed under Creative Commons Attribution 4.0 License

Submission Link: https://biomedres.us/submit-manuscript.php
16. Mullane K, Williams M (2014) Animal models of asthma: reprise or reboot? Biochem Pharmacol 87(1): 131-139.

17. Kumar RK, Herbert C, Foster PS (2016) Mouse models of acute exacerbations of allergic asthma. Respirology 21(5): 842-849.

18. Dai R, Yu Y, Yan G, Hou X, Ni Y, et al. (2018) Intratracheal administration of adipose derived mesenchymal stem cells alleviates chronic asthma in a mouse model. BMC Pulm Med 18(1): 1-9.

19. Leite LMB, Michelotto PV, Moura SAB, Capriglione LGA, Fragoso FYI, et al. (2019) Histopathologic evaluation, anesthetic protocol, and physiological parameters for an experimental Balb/c mouse model of asthma. Lung Breath J 3(1): 1-6.

20. Goodwin M, Sueblinvong V, Eisenhauer P, Ziats NP, LeClair L, et al. (2011) Bone marrow-derived mesenchymal stromal cells inhibit Th2-mediated allergic airways inflammation in mice. Stem Cells 29(7): 1137-1148.

21. Kang SY, Park DE, Song WJ, Bae BR, Lee JW, et al. (2017) Immunologic regulatory effects of human umbilical cord blood-derived mesenchymal stem cells in a murine ovalbumin asthma model. Clin \& Exp Allergy 47(7): 937-945.

22. Ou Yang HF, Huang Y, Hu XB, Wu CG (2011) Suppression of allergic airway inflammation in a mouse model of asthma by exogenous mesenchymal stem cells. Exp Biol Med (Maywood) 236(12): 1461-1467.

23. Ge X, Bai C, Yang J, Lou G, Li Q et al. (2013) Effect of mesenchymal stem cells on inhibiting airway remodeling and airway inflammation in chronic asthma. J Cell Biochem 114(7): 1595-1605.

24. Mohammadian M, Sadeghipour HR, Kashani IR, Jahromi GP, Omidi A, et al. (2016) Evaluation of simvastatin and bone marrow-derived mesenchymal stem cell combination therapy on airway remodeling in a mouse asthma model. Lung 194(5): 777-785.

25. Ogulur I, Gurhan G, Aksoy A, Duruksu G, Inci C, et al. (2014) Suppressive effect of compact bone-derived mesenchymal stem cells on chronic airway remodeling in murine model of asthma. Int Immunopharmacol 20(1): 101-109.

26. Royce SG, Rele S, Broughton BRS, Kelly K, Samuel CS (2017) Intranasal administration of mesenchymoangioblast-derived mesenchymal stem cells abrogates airway fibrosis and airway hyperresponsiveness associated with chronic allergic airways disease. FASEB J 31(9): 41684178.

27. Bonfield TL, Nolan (Koloze) MT, Lennon DP, Caplan AI (2010) Defining human mesenchymal stem cell efficacy in vivo. J Inflamm (Lond) 7(51): $1-12$.

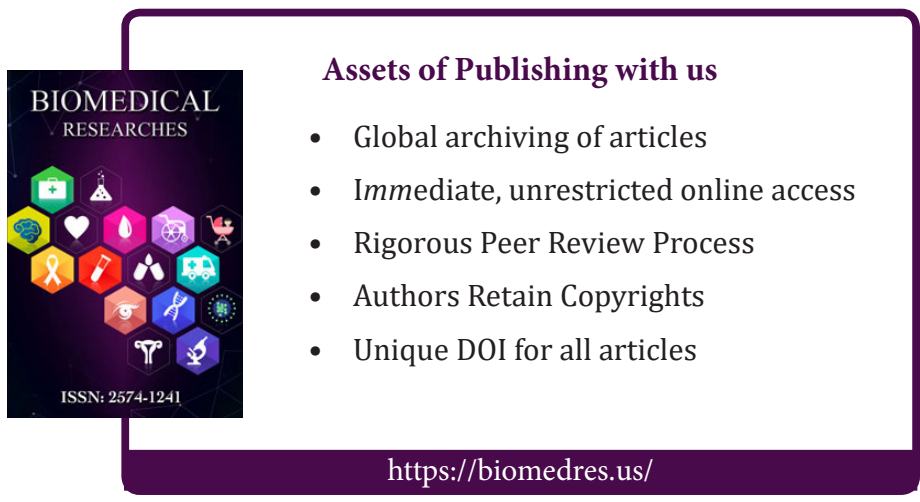

Copyright@ Leite LMB, Michelotto Jr PV, Moura SAB, Brofman, PRS, Senegaglia A| Biomed J Sci \& Tech Res| BJSTR. MS.ID.002655. 